\title{
Operationalising human rights for sexual and reproductive health: celebrations, achievements and challenges
}

\author{
Lindsay Edouard
}

\section{Progress}

The concept of human rights has progressed beyond the national politics in France and the USA of the late 18th century to numerous sectors, including health. Whereas governments are responsible for compliance with international human rights instruments, health professionals have a complementary role by respecting and promoting the rights of women, providing objective information for strengthening policy formulation, advocating for increased resource allocation, improving service delivery, and broadening concepts of related rights as pertaining to sexual and reproductive health.

As far back as the 16th century, a girl from Lyon in France justified her premarital sexual activities by arguing that "Paris est au Roi et mon corps est à moi" (Paris belongs to the King and my body belongs to me). This approach fits in the long line of events demonstrating that government has no business in the bedrooms of the nation.

The prominence of the women's movement led to major developments for sexual and reproductive health and rights ${ }^{1}$ with increasing involvement of parties as disparate as the United Nations (UN) Special Rapporteur on the Right to Health, ${ }^{2}$ professional medical associations ${ }^{3}$ and Amnesty International. ${ }^{4}$ Concerns for sexual and reproductive health, and specially the HIV epidemic, led to efforts to examine the relevance of human rights. ${ }^{5}$ With the special anniversaries in 2008 of numerous landmarks in the international human rights movement, it is apt to review the current status and implementation of those agreements as pertaining to sexual and reproductive health.

\section{Universal Declaration of Human Rights}

Adopted on 10 December 1948, the Universal Declaration of Human Rights (UDHR) reiterated the equal rights of men and women that had featured in the UN Charter of June 1945. The UDHR promotes the right to a standard of living that is adequate for health and well-being, including medical care. There are specific aspects of sexual and reproductive health that are implicit in its statements regarding "the right to marry and to found a family" in Article 16(1) and "motherhood and childhood are entitled to special care and assistance" in Article 25(2). Much stronger grounding for a rights-based approach to health had already been present in 1946, with the adoption of the constitution of the World Health Organization: its preface stated that "the enjoyment of the highest attainable standard of health is one of the fundamental rights of every human being without distinction of race, religion" but gender was not mentioned.

The UDHR became the basis for the development of current human rights legal instruments, including the two international covenants of 1966: the International Covenant on Economic, Social and Cultural Rights and the

J Fam Plann Reprod Health Care 2008; 34(1): 5-7

Larchmont, USA

Lindsay Edouard, FRCOG, FFFP, Member of the Editorial Advisory Board

Correspondence to: Professor Lindsay Edouard.

E-mail: soranae@gmail.com
International Covenant on Civil and Political Rights. Whereas the UDHR is purely a declaration, its statements became legally binding with those two covenants. The right to health is included in the International Covenant on Economic, Social and Cultural Rights and the specification, in Article 12(2)(a), for "the reduction of the stillbirth-rate and of infant mortality" is implicit for sexual and reproductive health. However, those early human rights considerations of health emphasised medical services for treating diseases as opposed to disease prevention and health promotion.

\section{Right to family planning}

There was no explicit mention of family planning in the UDHR in 1948 and the two subsequent covenants of 1966. At the 20-year review of UDHR during the International Conference on Human Rights in Teheran in 1968, it was agreed that women would benefit from their recognised rights only when complemented by reproductive freedom. With increasing concerns over the major threats from population growth and food security, family planning moved to centre stage, albeit in a population control mode that neglected education and underplayed the other rights of women.

Adopted on 13 May 1968, the Proclamation of Teheran states, in Resolution 16, that "Parents have a basic human right to determine freely and responsibly the number and the spacing of their children". The issue of family planning continued to be controversial but a common agenda between grassroots women's organisations and development agencies was ultimately successful. The World Population Plan of Action that was adopted at the World Population Conference in 1974 in Bucharest started the process to place human rights and the status of women in the wider context of population and development. ${ }^{6}$

\section{Primary health care}

Adopted at the International Conference on Primary Health Care on 12 September 1978, the Declaration of Alma-Ata acknowledged the role of primary health care for social justice as part of development efforts (Article V), reaffirmed that health is a fundamental right needing a multisectoral approach (Article I) and specified that family planning is a component of maternal and child health, which is an essential element of primary health care (Article VII). However, the binding obligation of countries for the right to family planning had to wait for the Women's Convention which was, at that time, undergoing the final steps of the drafting stage.

\section{Women's Convention}

Having its origins largely in the UDHR, the Convention on the Elimination of All Forms of Discrimination against Women, also known as the Women's Convention, was adopted in 1979 .

The Women's Convention is the international human rights treaty providing a cornerstone for sexual and reproductive health, which is considered along with socioeconomic issues, education and employment, whilst paying special attention to the plight of rural women. Addressing access by and opportunities for women, Article 1 defines discrimination "irrespective of their 
marital status" whereas in its consideration of "matters relating to marriage and family relations", Article 16(1)(e) mentions the "same rights to decide freely and responsibly on the number and spacing of their children and to have access to the information, education and means to enable them to exercise these rights". Whereas numerous parts of the Convention have a direct impact on health, Article 12 calls for appropriate measures for "access to health care services, including those related to family planning" and "appropriate services in connection with pregnancy, confinement and the postnatal period, granting free services where necessary". Article 14(2)(b) calls for measures to enable rural women to have access to "information, counselling and services in family planning" whereas the health and safety of working women including "the safeguarding of the function of reproduction" is specified in Article 11(1)(f).

There was no mention of violence against women in the Women's Convention. However, the Committee on the Elimination of Discrimination against Women (CEDAW), which monitors its implementation, issued general recommendations pertaining to violence against women, female circumcision, women with disabilities and HIV between 1989 and 1992. In 1999, its General Recommendation 24 strongly endorsed sexual and reproductive health recognising, amongst others, refugees and "women in prostitution" as vulnerable groups.

After ratifying a human rights treaty, a country should implement its recommendations but can limit its obligations by entering reservations to certain articles. While intended for specific situations as opposed to generalities, this process has been abused through the entering of numerous reservations. A critical analysis of reservations, to identify those that are inappropriate, should be followed by lobbying for their withdrawal. Regular reporting on progress, an obligation of government, should ideally be supplemented by shadow reports from nongovernmental organisations (NGOs) such as professional associations. As slick official reports can gloss over essential issues, it is opportune that the CEDAW Optional Protocol of 2000 allows for additional accountability through direct reporting by other parties, whether in groups or as individuals. The Committee analyses the reports prior to a constructive face-to-face dialogue with country delegations and the formulation of recommendations, socalled 'Concluding Comments', for action: the government report and the summary of the 'Concluding Comments' are made public and valuable for discussion at the national level. CEDAW has repeatedly expressed grave concerns at sexual and reproductive health service delivery.

There are close links between the Women's Convention and the Convention on the Rights of the Child, especially for the girl child. Adopted in 1989 and as yet not ratified by only two countries, the Children's Convention applies to those aged under 18 years, but in practice the rights of adolescent girls have been given less attention when compared to those of the young child. ${ }^{7}$ The right of children for access to health services includes measures "to develop preventive health care, guidance for parents and family planning education and services" as stated in Article 24(2)(f). Article 3(1) specifies that the primary consideration should consist of the best interests of the child who, according to Article 12(1), has the right to free expression of views which should be "given due weight in accordance with the age and maturity". This issue of evolving capacity of the child, as recognised in Article 5, is relevant for the Fraser Guidelines of 1985 and Axon decision of 2006 for the provision of sexual and reproductive health services to minors. ${ }^{8}$

\section{Vienna Declaration}

Adopted on 25 June 1993 by the World Conference on Human Rights, the Vienna Declaration and Programme of Action established that the rights of women "are an inalienable, integral and indivisible part of universal human rights" (Paragraph 18), specifying "a woman's right to accessible and adequate health care and the widest range of family planning services" (Paragraph 41) and the need to address gender-based violence (Paragraphs 18 and 38). The World Conference on Human Rights gave much prominence to the rights of women as a result of a massive global campaign by an alliance of almost a thousand NGOs, that pointed out the lack of rights in the health field, the global concerns on sexual and reproductive health and the need to strengthen implementation of the Women's Convention. The stage was set for a swift rights-based discourse leading to major developments during the following 2 years at the intergovernmental conferences in Cairo and Beijing.

\section{New development agenda}

The International Conference on Population and Development, held in Cairo in 1994, adopted a Programme of Action that stressed the primordial nature of the rights of individuals with informed choice for the voluntary utilisation of services, as opposed to imposition of governments, in all matters pertaining to sexual and reproductive health. Substantial lack of resources led to major concerns as exemplified by the inclusion, in Paragraph 7.12, of the phrase "means to do so" to promote operationalisation of the right to family planning.

The Fourth World Conference on Women, held in Beijing in 1995, adopted a Platform for Action which went further by stating, in Paragraph 96, that the "human rights of women include their right to have control over and decide freely and responsibly on matters related to their sexuality, including sexual and reproductive health". 9

The above three intergovernmental conferences of the 1990s were instrumental in strengthening the implementation of the Women's Convention: by initiating the movement for a comprehensive agenda for the empowerment of women, their recommendations, though not legally binding, provided governments with norms and standards to aim for. Nevertheless, grey areas persist and frontiers keep being extended. Adopted in December 2006, the Convention on the Rights of Persons with Disabilities addressed the issue of family planning for those individuals with a specification, in Article 23(1)(b) that "the means necessary to enable them to exercise these rights are provided".

\section{Promoting policies}

Lying largely in the community-wide domain of social and economic rights that apply mainly in private settings, ${ }^{10}$ the rights of women were for long neglected as opposed to the broad publicity given to the specific violations of political and civil rights of individuals. The early human rights instruments emphasised medical outcomes, such as stillbirth, as opposed to positive concepts of health. The special circumstances around sexual and gender-based violence, trafficking, migrants and refugees present challenges that are very different from general topics pertaining to the status of women and their promotion into leadership positions for long-term benefits. Health, as pertaining to sexuality and reproduction, necessitates utilisation of the principles of human rights for informed choice besides the formulation of wide-ranging socioeconomic policies to promote gender equity. ${ }^{11}$ 
Health professionals are well placed and have a duty to respect and promote the rights of women. Special efforts are needed to contribute to shadow reports, demonstrate the special vulnerability of specific groups through epidemiological evidence, become acquainted with government reports and examine the implications of recommendations from monitoring bodies. The websites of the Office of the United Nations High Commissioner for Human Rights (www.unhchr.ch) and CEDAW (www.un.org/womenwatch/daw/cedaw), among others, provide valuable information: widespread dissemination of their contents ought to increase the involvement of health professionals.

The lack of an appropriate perspective on rights and gender in the training of health professionals is being addressed in both pre-service and in-service training..$^{12}$ Despite the elusive nature of consensus on certain issues for sexual and reproductive health and related rights, ${ }^{13,14}$ human rights are being increasingly used in conceptual and operational frameworks but an objective approach is needed to interpret the specific sociocultural and political context of evolving societies. ${ }^{15}$ A major challenge for donors consists of using human rights as one of the criteria influencing the level of funding to countries.

Besides the disjunction between treaty ratification and policy formulation, the operationalisation of rights into service delivery has been hindered by a lack of appreciation of related concepts and training. Care must be accessible, meet standards of quality and pay special attention to vulnerable groups. Duty bearers, primarily governments and service providers, should fulfil their obligations $^{16}$ but, most importantly, the target groups should be empowered to claim those services as rightsholders. ${ }^{17}$ Health professionals should appreciate their crucial role in advocacy, leadership and partnerships. ${ }^{18}$

Implementation of interventions should be subjected to monitoring, ${ }^{19}$ rights-based programming being no exception. Process indicators include the availability of and access to services, besides their coverage and quality. Attempts should also be made to measure, among others, community participation for planning and resource allocation for budgeting. Time trends in disparities for vulnerable and underserved groups present a recurring theme, and assessment of the rational integration of reinforcing interventions can also inform programme priorities.

\section{Statements on funding and competing interests \\ Funding None identified.}

Competing interests None identified.

\section{References}

1 Newman K. Guidelines for the Use of the IPPF Charter on Sexual and Reproductive Rights. London, UK: International Planned Parenthood Federation, 1997.

2 Hunt P. Right to the highest attainable standard of health. Lancet 2007; 370: 369-371.

3 Asher J, Hamm D, Sheather J. The Right to Health: A Toolkit for Health Professionals. London, UK: British Medical Association and Commonwealth Medical Trust, 2007; 13-15, 17-18.

4 Schlitt S. Human rights perspectives on abortion. Session 2: Rights and Risks. Presentation at the Global Safe Abortion Conference, London, UK, 23-24 October 2007.

5 Gruskin S, Mills EJ, Tarantola D. History, principles and practice of health and human rights. Lancet 2007; 370: 449-455.

6 Finkle JL, Crane BB. The politics of Bucharest: population, development and the new international economic order. Popul Dev Rev 1975; 1: 87-114.

7 Hodgkin R, Newell P. Implementation Handbook for the Convention on the Rights of the Child. New York, NY: United Nations Children's Fund, 2002; 179, 362-364.

8 Bridgeman J. Young people and sexual health: Whose rights? Whose responsibilities? Med Law Rev 2006; 14: 418-424.

9 Women's Environment and Development Organization. Beijing Betrayed - Women Worldwide Report that Governments Have Failed to Turn the Platform into Action. New York, NY: Women's Environment and Development Organization, 2005; 10, 13, 27, 117.

10 Wollstonecraft M. A Vindication of the Rights of Woman with Strictures on Political and Moral Subjects. Boston, MA: by Peter Edes for Thomas and Andrews, 1792. http://www.bartleby.com/144/ [Accessed 22 October 2007].

11 Doyal L. Sex, gender and health: the need for a new approach. BMJ 2001; 323: 1061-1063.

12 World Health Organization. Transforming Health Systems: Gender and Rights in Reproductive Health (Document WHO/RHR/01.29). Geneva, Switzerland: World Health Organization, 2001; 148-151, 170-174, 179-184, 202-203.

13 Miller AM. Sexual but not reproductive: exploring the junction and disjunction of sexual and reproductive rights. Health Hum Rights 2000; 4: 68-109.

14 MacDonald TH. Health, Human Rights and the United Nations Inconsistent Aims and Inherent Contradictions? Abingdon, UK: Radcliffe Publishing, 2007

15 Amin S, Hossain S. Women's reproductive rights and the politics of fundamentalism: a view from Bangladesh. Am Univ Law Rev 1995; 44: 1319-1343.

16 Elson D. Budgeting for Women's Rights: Monitoring Government Budgets for Compliance with CEDAW. New York, NY: United Nations Development Fund for Women, 2006; $17-19,141-143$.

17 Office of the United Nations High Commissioner for Human Rights. Frequently Asked Questions on a Human Rights-based Approach to Development Cooperation. Geneva, Switzerland: United Nations, 2006.

18 United Nations. Intensification of Efforts to Eliminate All Forms of Violence Against Women (United Nations General Assembly. Document A/62/201). New York, NY: United Nations, 2007.

19 World Health Organization. Women's Health and Human Rights: Monitoring the Implementation of CEDAW. Geneva, Switzerland: World Health Organization, 2007; 10, 25-27, 34-37.

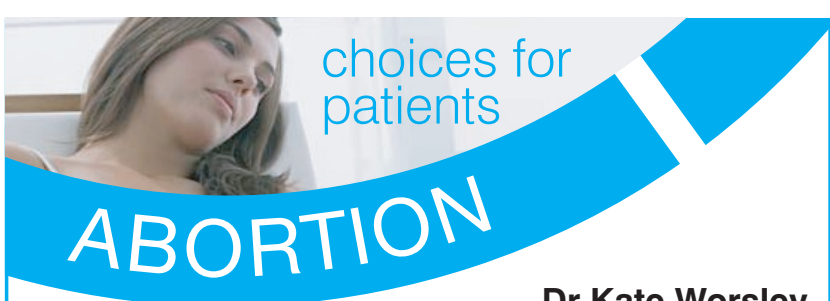

Head of Medical Development - Marie Stopes International

Many women who fall pregnant unexpectedly do not wish to continue with their pregnancy and it is important to provide them with choice, support and professional abortion services to help them get their lives back on track.

Marie Stopes International now sees one third of all women seeking abortion in England and Wales. As experts in this field they have pioneered and modernised abortion provision making them first choice amongst healthcare professionals.

Medical abortion - currently one third of women between 4-9 weeks gestation having abortion, choose the abortion pill. At Marie Stopes centres this has been simplified to 2 visits over 2 days.

Surgical abortion - women prefer a quick, convenient appointment and the majority are now choosing Marie Stopes one visit only appointments where the consultation and treatment are provided on the same day. A choice of anaesthesia including local, conscious sedation and general anaesthetic is also offered by the organisation.

A 24 hour appointment booking line and aftercare service on 08451203644 offers all the support and advice clients need.

Call for a Marie Stopes International GP Sexual Health Pack containing information on current abortion treatment choices and referral guidelines.

08451203644 www.mariestopes.org.uk

working with you...

CONTRACEPTION • HEALTH SCREENING · STERILISATION • VASECTOMY • ABORTION

